nutrients by tree crops. Acta Hort. 179:395404.

Atkinson, D. and J.S. Chauhun. 1987. The effect of paclobutrazol on the water use of fruit plants at two temperatures. J. Hort. Sci. 62:421-426.

Atkinson, D. and C.M. Crisp. 1983. The effect of some plant growth regulators and herbicides on root system morphology and activity. Acta Hort. 136:21-28.

Bausher, M.G. and G. Yelenoaky. 1986. Sensitivity of potted citrus plants to top sprays and soil applications of paclobutrazol. HortScience 21:141-143.

Bowling, D.J.F. 1976. Uptake of ions by plant roots. Chapman and Hall, London. p. 159.

Couvillon, G.A. and A. Erez. 1980. Rooting, survival, and development of several peach cultivars propagated from semihardwood cuttings. HortScience 15:41-43.

Curry, E.A. 1988. Chemical control of vegetative growth of deciduous fruit trees with paclobutrazol and RSW0411. HortScience 23:470-475.

DeJong, T.M. and J.F. Doyle. 1984. Leaf gas exchange and growth responses of mature 'Fantasia' nectarine trees to paclobutrazol. J. Amer. Soc. Hort. Sci. 109:878-882.

Early, J.D. and G.C. Martin. 1988. Sensitivity of peach seedling vegetative growth to paclobutrazol. J. Amer. Soc. Hort. Sci. 113:23-27.

Jones, J.B. 1977. Elemental analysis of soil extrActa and plant tissue ash by plasma emission spectroscopy. Commun. Soil Sci. Plant Anal. 8(4):349-365

Jones, J.B. 1985. How-to-do-it: Growing plants hydroponically. Amer. Biol. Teacher 47:356358.

Looney, N.E. and J.E. McKellar. 1987. Effect of foliar- and soil surface-applied paclobutrazol on vegetative growth and fruit quality of sweet cherries. J. Amer. Soc. Hort. Sci. 112:71-76.

Martin, G. C., F. Yoshikawa, and J.H. LaRue. 1987. Effect of soil applications of paclobutrazol on vegetative growth, pruning time, flowering, yield, and quality of 'Flavorcrest' peach. J. Amer. Soc. Hort. Sci. 112:915-921.

Rieger, M. 1989. Pressure- and transpiration-induted flow methods for estimating hydraulic resistance in peach. HortScience 24:648-650.

Sanchez, L. E., F. Prieto, and M. Becerra. 1988. Control of vegetative growth of stone fruits with paclobutrazol. HortScience 23:467-470.

Shaltout, A. D., A.T. Salem, and A.S. Kilany. 1988. Effect of pre-bloom sprays and soil drenches of paclobutrazol on growth, yield, and fruit composition of 'Roumi Red' grapes. J. Amer. Soc. Hort. Sci. 113:13-17.

Stan, S., I. Popescu, M. Cotorobai, and M. Radulescu. 198.5. Vegetative growth control of pear trees with cultar. Fifth Intl. Symp. Growth Regulat. Fruit Prod., Bologna-Rimini, Italy, p. 113. (Abstr.)

Steffens, G.L. and S.Y. Wang. 1984. Physiological changes induced by paclobutrazol (PP333) in apple. Acta Hort. 146:135-142.

Swietlik, D. and S.S. Miller. 1983. The effect of paclobutrazol on growth and response to water stress of apple seedlings. J. Amer. Soc. Hort. Sci. 108:1076-1080.

Wang, S. Y., J.K Byun, and G.L. Steffens. 1985. Controlling plant growth via the gibberellin biosynthesis system. II. Biochemical and physiological alterations in apple seedlings. Physiol. Plant. 63:169-175.

Williamson, J. G., D.C. Coston, and L.W. Grimes. 1986. Growth responses of peach roots and shoots to soil and foliar-applied paclobutrazol. HortScience 21:1001-1003.

Wood, B.W. 1984. Influence of paclobutrazol on selected growth and chemical characteristics of young pecan seedlings. HortSciencc 19:837-839.

\title{
Survival of Young Cold-hardened 'Hamlin' Orange Trees at - 6.7C
}

\author{
George Yelenosky \\ Horticultural Research Laboratory, Agricultural Research Service, U.S. \\ Department of Agriculture, 2120 Camden Road, Orlando, FL 32803
}

Additional index words. Citrus sinensis, membrane leakage, conductivity, $\mathrm{O}_{2}$ uptake, acclimation, freeze survival

Abstract. Potted greenhouse-grown, l-year-old 'Hamlin' orange [Citrus sinensis (L.) Osbeck] trees on 1.5-year-old rough lemon (C. jambhiri Lush.) rootstock were temperature-conditioned for 6 consecutive weeks in a controlled-environment room to test cold-hardening ability. Holding at $15.6 \pm 0.6 \mathrm{C}$ during $12-\mathrm{hr}$ days $\left[425 \mu \mathrm{mol} \cdot \mathrm{s}^{-1} \cdot \mathrm{m}^{-2}\right.$ photosynthetic photon flux (PPF) at top of trees] and 4.4C during nights resulted in $100 \%$ tree survival and no leaf loss "after $4 \mathrm{hr}$ of $-6.7 \mathrm{C}$ in a dark freeze test room. Unhardened greenhouse trees were killed to rootstock. Solute efflux $\left(\mathrm{dS}^{-1} \mathrm{~m}^{-1}\right)$ from unhardened frozen leaves was $>\mathbf{2 0}$-fold that from frozen leaves on hardened trees and nonfrozen leaves on unhardened trees. Oxygen uptake was not significantly impaired in frozen hardened leaves. No $\mathrm{O}_{2}$ uptake was evident for frozen unhardened leaves.

'Hamlin' orange is one of the world's major early maturing (October-January) sweet orange cultivars and is second to the latematuring (March-June) major juice orange, 'Valencia,' in hectarage and number of trees in Florida. The 1988, commercial citrus tree inventory (Fla. Agr. Stat. Ser., 1988) showed about a $31 \%$ increase in 'Hamlin' plantings to $\approx 61,400$ ha from a low of 46,900 in 1986 and to 16 million from 12 million trees. Much of this increase is in replanting of areas devastated after freezes in the 1980s. The choice of 'Hamlin' for replanting frozen-out areas apparently was partly based on its high yield potential (Fla. Agr. Stat. Ser., 1989; C.J. Hearn, personal communication); early maturing of fruit, which decreases the risk of total loss to freezes; and wide acceptability in fresh fruit and processed juice where blending with 'Valencia' orange increases color acceptability (Wutscher and Bistline, 1988). However, there are few published reports on cold hardiness of 'Hamlin' (Hearn et al., 1963) because it is a relatively new cultivar in extensive plantings of freeze-risk areas.

The objective of this study was to test the cold-hardening ability of 'Hamlin' on a coldsensitive rootstock in a severe freeze situation to obtain basic information on the freeze survival of this cultivar and its potential in low-temperature stress tolerance (Ashworth, 1986; Barrett, 1981).

Forty-five trees, matched for uniform growth and appearance, were selected from a greenhouse population of 100 one-year-old

Received for publication 3 Apr. 1989. Mention of a trademark, warranty, proprietary product, or vendor does not constitute a guarantee by the USDA and does not imply its approval to the exclusion of other products or vendors that may also be suitable. The cost of publishing this paper was defrayed in part by the payment of page charges. Under postal regulations, this paper therefore must be hereby marked advertisement solely to indicate this fact.
'Hamlin' orange trees on I. S-year-old rough lemon rootstock. Single trees were grown in 2.5-liter plastic pots containing Pro-Mix (shredded sphagnum peat with equal parts of vermiculite and perlite and major and minor elements added; Premier Brands, Inc., New Rochelle, N.Y.). Rootstock were from openpollinated seed from a single source tree near Leesburg, Fla. 'Hamlin' scions were from state-registered budwood from a single source tree near Dundee, Fla. Buds were grafted, $10 \mathrm{~cm}$ above soil level, into 5-month-old rootstock. Single-stem trees were maintained in a $50 \%$ shaded greenhouse under natural day conditions. Air temperatures in the greenhouse ranged from $32 \mathrm{C}$ during the day to $15 \mathrm{C}$ at night. Relative humidity ranged from $35 \%$ during the day to $98 \%$ at night. Trees were watered every 2 days and each tree was fertilized monthly with $12 \mathrm{~N}-5 \mathrm{P}$ $4.3 \mathrm{~K}$ liquid fertilizer containing microelements at $100 \mathrm{ml}$ per pot. Trees averaged 88 $\pm 4 \mathrm{~cm}$ in total height, $0.7 \pm 0.2 \mathrm{~cm}$ stem diameter $10 \mathrm{~cm}$ above budunion, $1.4 \pm 0.1$ $\mathrm{cm}$ mid-diameter of rootstock, and $29 \pm 2$ leaves.

Fifteen trees were exposed to a cold-hardening regime of 6 consecutive weeks of 12$\mathrm{hr}$ days $\left(425 \mu \mathrm{mol} \cdot \mathrm{s}^{-1} \cdot \mathrm{m}^{-2} \mathrm{PPF}\right.$ at the top of the trees) with $15.6 \mathrm{C}$ days and $4.4 \mathrm{C}$ nights, and 30 trees were left in the greenhouse. Hardened trees were frozen along with 15 unhardened trees in a controlled-freeze chamber (Yelenosky, 1975). In controlled freezes, temperatures were lowered $1.1 \mathrm{C} / \mathrm{hr}$ from $4.4 \mathrm{C}$ to $-6.7 \mathrm{C}$ for $4 \mathrm{hr}$, and then returned to $4.4 \mathrm{C}$ at $1.1 \mathrm{C} / \mathrm{hr}$. Temperatures were measured to $\pm 0.6 \mathrm{C}$; relative humidity was $60 \% \pm 5 \%$. Stem temperatures were measured with 24-gauge T-type thermocouples taped to the main stem of five trees and connected to a 15-channel digital recorder, and were within $1 \mathrm{C}$ of ambient air before trees froze. Leaf freezing was noted every hour by observing water soaking in the leaves. Soil temperatures did not drop below $1 \mathrm{C}$. Trees were kept at $\approx 25 \mathrm{C}$ for $3 \mathrm{hr}$ after re- 
Table 1. Freeze injury 5 weeks after freezing of 'Hamlin' orange trees on rough lemon rootstocks after $4 \mathrm{hr}$ at $-6.7 \pm 0.6 \mathrm{C}$ in a controlled-temperature chamber.

\begin{tabular}{|c|c|c|c|c|c|c|}
\hline \multirow[b]{2}{*}{ Treatment } & \multicolumn{5}{|c|}{ Leaves $^{2}$} & \multirow{2}{*}{$\begin{array}{c}\text { Dieback of } \\
\text { main stem } \\
(\%)\end{array}$} \\
\hline & $\begin{array}{l}\text { Trees } \\
\text { (No.) } \\
\end{array}$ & $\begin{array}{c}\text { Killed } \\
(\%)\end{array}$ & $\begin{array}{l}\text { Injured }^{y} \\
(\%)\end{array}$ & $\begin{array}{c}\text { Leakage } \\
(\%)\end{array}$ & $\begin{array}{c}\mathrm{O}_{2} \text { uptakex } \\
\left(\mu \mathrm{i} \cdot \mathrm{hr}^{-1} \cdot \mathrm{g}^{-1} \mathrm{dry} w \mathrm{w}\right)\end{array}$ & \\
\hline Cold-hardened, frozen & 15 & 0 & $3^{y}$ & $0.9 \mathrm{a}$ & $163 \pm 3 b$ & 0 \\
\hline Non-hardened, frozen & 15 & 100 & $\cdots$ & $20 \mathrm{~b}$ & $0 \mathrm{a}$ & 100 \\
\hline Not frozen & 15 & 0 & 0 & $0.9 \mathrm{a}$ & $190 \pm 9 c$ & 0 \\
\hline
\end{tabular}

${ }^{2}$ Mean separation in columns by LSD, 5\% level.

'Leaves developed bleached areas between major veins.

moval from the freeze chamber and returned to greenhouse for 5 weeks of observation for injury. Trees were rated for freezing injury using percentage of leaf kill and stem dieback.

Tolerance to internal ice was determined in leaves using electrolyte leakage, $\mathrm{O}_{2}$ uptake, and permanent visual damage. Two hours after the freeze test, one leaf, selected randomly from each of five trees per treatment, was detached with a razor cut at the end of the petiole. Whole leaves were immersed to the depth of the winged petiole in $25 \mathrm{ml} 2 \times$ distilled, deionized water and placed at $4.4 \mathrm{C}$ in the dark for $24 \mathrm{hr}$. Electrolyte leakage, before and after $5 \mathrm{~min}$ of boiling, was determined at 24C (Markson Conductivity Meter, Del Mar, Calif.). Specific ion leakage, using the same methods and atomic absorption analysis, was done 72 . $\mathrm{hr}$ postfreeze on three leaves per treatment to estimate membrane damage in leaves that developed surface bleaching but no necrosis.

Oxygen uptake was measured on leaf disks $(6 \mathrm{~mm}$ in diameter) immediately after the freeze test as another index of membrane integrity and cell viability. Composite disk samples consisted of two disks per leaf from each of four leaves from the upper one-third of each of five trees per treatment. Samples were replicated three times with one 40-disk sample in each of three flasks per treatment. Oxygenconsumption was measured at $30 \pm$ $0.2 \mathrm{C}$ with a differential respirometer (Gibson Medical Electronics, Middleton, Wis.) and $0.2 \mathrm{ml}$ of $10 \% \mathrm{KOH}$ with paper wick in the center well. Readings were taken at 10 min intervals (flasks closed) for $1 \mathrm{hr}$ after 30 min of equilibration. Oxygen uptake was calculated per gram of oven-dry weight of leaf tissue. Data were analyzed by linear regression and correlation.

These young 'Hamlin' orange trees survived $-6.7 \mathrm{C}$ for $4 \mathrm{hr}$ with little or no injury (Table 1), as did 'Valencia' orange on Rusk citrange rootstock and a different hardening regime (Yelenosky, 1978). Thus, both 'Hamlin' and 'Valencia' express an adequate degree of potential to survive severe freeze conditions in, Florida, although different coldhardening regimes and rootstock were used (Whitney, 1985). Optimum cold-hardening conditions are not established, but -6.7C for $4 \mathrm{hr}$ with little or no injury is considered close to maximum cold-hardening potential for $C$. sinensis (Yelonsky, 1985). However, this level of cold hardening to survive $-6.7 \mathrm{C}$ is not well-established under natural conditions.

In this study, temperature exotherms indicated freezing in the stems between -4.9 and $-6.2 \mathrm{C}$, and all hardened and unhardened trees were observed to have extensive water-soaking (Young and Peynado, 1967) in the leaves when temperature reached $-6.7 \mathrm{C}$ during the freeze. Internalize (presumably intercellular, especially for coldhardened trees) apparently was extensive in leaves and bark for at least $4 \mathrm{hr}$ at $-6.7 \mathrm{C}$ ambient air and for another 3 to $4 \mathrm{hr}$ as temperatures returned to $4.4 \mathrm{C}$. The presence of ice for 7 to $8 \mathrm{hr}$ apparently was not injurious to membrane integrity of hardened trees, as determined by leakage and $\mathrm{O}_{2}$ uptake (Table $1)$.

Leakage, as percentage of conductivity of postfreeze electrolyte efflux to total efflux after boiling leaves, was $>20$ times that for hardened, frozen leaves, for either unhardened unfrozen controls, or cold-hardened, frozen leaves. Three percent of total leaves observed were bleached 1 day after the freeze test. Atomic absorption analysis of efflux identified a slight increase in leakage of $\mathrm{K}^{+}$ and $\mathrm{Zn}^{++}$in bleached vs. nonbleached leaves. Bleaching did not result in leaf kill or abscission and was not reversed during 5 weeks of observation. Chlorophyll destruction in citrus leaves apparently can be caused by chilling injury (Yelenosky, 1982), internal ice, and surface frost during natural freezes with high dewpoints (personal observation).

The $14 \%$ reduction in $\mathrm{O}_{2}$ uptake in coldhardened, frozen leaves in contrast to unhardened, unfrozen controls (Table 1) and lack of significant electrolyte leakage suggest some alteration in the respiratory process/ enzyme system without major injury to membrane integrity. The measured respiratory activity was linear with time $(r=0.99)$ during the 1-hr determination with a slope of 2.8 for cold-hardened, frozen leaves and 3.2 for unhardened nonfrozen leaves, and a $\mathrm{y}$-intercept of zero. The rate of $\mathrm{O}_{2}$ uptake, membrane leakage and visual observations coincide to illustrate considerable ice tolerance in leaves of cold-hardened 'Hamlin' orange, similar to that in 'Valencia' orange.
One of the prevailing views in plant cold hardiness is that internal ice is intercellular and a major obstacle for freeze survival is lack of tolerance to ice-induced cell plasmolysis (Anderson et al., 1983).

The results of this and a related study (Yelenosky, 1988) suggest that 'Hamlin' is similar to 'Valencia' in its potential to cold harden. The freeze tolerance of 'Hamlin' during the severe 1962 freeze in Florida, however, was rated slightly better than 'Valencia' (Hearn et al., 1963) and 'Hamlin' trees also had better recovery following the freeze (Cooper et al., 1969).

\section{Literature Cited}

Anderson, J. A., L.V. Gusts, D.W. Buchanan, and M.J. Burke. 1983. Freezing of water in citrus leaves. J. Amer. Soc. Hort. Sci. 108:397-400.

Ashworth, E.N. 1986. Freezing injury in horticultural crops-research opportunities. HortScience 21:1325-1328.

Barrett, H.C. 1981. Breeding cold-hardy citrus scion cultivars. Proc. Intl. Soc. Citricult. 1:6166.

Cooper, W. C., R. Fenton, and W.H. Henry. 1969. Recovery of Florida citrus trees from freeze injury. Proc. First Intl. Citrus Symp. 2:565-569.

Florida Agricultural Statistics Service. 1988. Commercial citrus tree inventory. Orlando, Fla.

Florida Agricultural Statistics Service. 1989. Citrus summary 1987-88. Orlando, Fla.

Hearn, C. J., W.C. Cooper, R.O. Register, and R. Young. 1963. Influence of variety and rootstock upon freeze injury to citrus trees in the 1962 Florida freeze. Proc. Fla. State Hort. Soc. 76:75-81.

Whitney, J.D. 1985. Florida citrus freeze losses and recovery in the field. Trans. Amer. Soc. Mech. Eng. 31:1-21.

Wutscher, H.K. and F.W. Bistline. 1988. Rootstock influences juice color of 'Hamlin' orange. HortScience 23:724-725.

Yelenosky, G. 1975. Cold hardening in citrus stems. Plant Physiol. 56:540-543.

Yelenosky, G. 1978. Cold hardening 'Valencia' orange trees to tolerate $-6.7 \mathrm{C}$ without injury. J. Amer. Soc. Hort. Sci. 103:449-452.

Yelenosky, G. 1982. Chilling injury in leaves of citrus plants at 1.7C. HortScience 17:383-387.

Yelenosky, G. 1985. Cold hardiness in citrus. Hort. Rev. 7:201-238.

Yelenosky, G. 1988. Capacity of citrus flowers to supercool. HortScience 23:365-367.

Young, R. and A. Peynado. 1967. Freezing and water-soaking in citrus leaves. Proc. Amer. Soc. Hort. Sci. 91:157-162. 